\title{
Daniel Tammet: Born on a Blue Day: Inside the Extraordinary Mind of an Autistic Savant
}

\author{
Free Press, New York, NY, 2007, 256 pp., \$14.00 (paper) \\ Ernst VanBergeijk
}

Published online: 3 September 2009

(C) Springer Science+Business Media, LLC 2009

This is a NY Times bestselling memoir from Daniel Tammet, a 28 year old, who has an autism spectrum disorder and is a savant. Daniel's story is both inspirational and instructive. Daniel has a rare neurological condition know as synesthesia, which enables him to experience numbers as colors, shapes, and textures. He parlays this unusual ability into setting a record breaking recitation of over 22,000 decimal places of the number Pi and a documentary film about his life and abilities. His extraordinary abilities extend beyond numbers. Daniel has the ability to learn languages in a matter of days. After his record breaking recitation of $\mathrm{Pi}$ he appeared upon Late Night with David Letterman and even a talk show in Iceland where he spoke Icelandic for the entire show- a language that he only learned four days before the taping of the show.

The fascinating aspect of this book is not Daniel's brush with fame. Rather, it is his daily struggles on his road to independence. Daniel lives independently and supports himself through websites he created that teach foreign languages. He reviews his life with candor and insightfulness. He also contributes to our knowledge base by volunteering to participate in dozens of brain studies. The documentary based upon his life is aptly named Brainman, a play on the name of the 1988 Academy Award winning film Rainman, where Dustin Hoffman portrayed a savant whose autism is more severe than Daniel's.

The most inspirational aspect of the memoir is Daniel's longing to connect with others around him. Many of us assume individuals on the autism spectrum prefer to be alone. Daniel describes his loneliness and his joy in finding love. He falls in love with someone he met on-line and has a long term relationship with this person to this day. Through learning to love, Daniel begins to appreciate the love and support he received as a young child from his parents and siblings. He takes stock of what helped him achieve all that he has thus far and now actively nurtures those relationships. His willingness to take risks and move outside of his comfort zone is an inspiration to us all.
E. VanBergeijk ( $\square)$

New York Institute of Technology, Vocational Independence Program, 300 Carleton Avenue, Room 112 Independence Hall, Central Islip, NY 11722, USA

e-mail: evanberg@nyit.edu 